\title{
In flight or in plight? The current state of audio visual departments in Australian CAEs
}

\author{
Mark Norman \\ Audiovisual Services Information Resources Centre \\ Macarthur Institute of Higher Education
}

\begin{abstract}
Given that the Commonwealth Government intends to maximise the number of students in tertiary education with a minimum increase in funding, this research aimed to review the effects of reduced Government funding on the services of Audio Visual Departments between 1980 and 1986. This study sets a "bench mark" on the current state of Audio Visual Departments. The scenario formed by the responses is not encouraging. Funding cuts, static or reduced staff profiles, aging equipment and an increased demand for resource production and training courses are just a few of the problems facing managers of the Audio Visual Departments.

If Audio Visual Departments are to provide effective and efficient services to meet the demands of their institution's academic and administrative staff, and the students, then there must be immediate "catch up" funding to allow managers to replace obsolete equipment built up over the last eight to twelve years. The effects of devaluation and inflation must be recognised and adjustments made with each funding grant to Colleges of Advanced Education. Most importantly, institution management must work with the Audio Visual Department's clients to determine the level of service required from the Department to effectively support training and development of competent graduating students within all disciplines.
\end{abstract}

The aim of this study, which was undertaken during 1986, was to provide an accurate picture of the current state of Audio Visual Departments (See reference note 1) within Australian Colleges of Advanced Education, with specific reference to the departments' budgets, level of staffing, 
audiovisual resource production, audiovisual training courses, and staff development within the Department and within the Institution. Collective, factual information covering all aspects of the operation of Audiovisual Departments was needed to assess the "flight or plight" of the Departments. The study did not seek to examine the role each Audiovisual Department plays within its CAE in promoting educational technology; supporting various media, communication, fine arts and curriculum development units; or assessing the efficacy of the services and expertise provided by the Audiovisual Department. These are very important issues and should be addressed by further specific research.

It is hoped that the findings from this research will assist Audiovisual Department managers to examine the state of Departments throughout Australia, in comparison to their own Department. The managers, together with the senior management of the institution, may be able to mount an effective submission for increased funding from the appropriate government bodies. Given that the Commonwealth Government intends to maximise the number of students in tertiary education with a minimum increase in funding, this research aimed to reveal the effects of this reduction in Government funding on the services of Audiovisual Departments between 1980 and 1986.

The Departments represented in this research report, whether they be located in small or large institutions, collectively form a picture of a typical Audiovisual Department in an Australian College of Advanced Education.

Regardless of how well an Audiovisual Department is supported by funding and staffing to provide the professional services offered, we cannot deny that the attitudes of academic staff determine whether educational technology is to be integrated into an institution's academic courses. It is unfortunate that a majority of academic staff and institution librarians still consider print materials to be the most appropriate resources for their teaching programs (Myers, 1979). Steele (1987) believes the proponents of educational technology need to convince others of the benefits of investing in additional or alternative strategies designed to improve the efficiency and effectiveness of students' learning. Hedberg $(1980,23)$ states that senior administrators consider that educational technology has failed to "...deliver the goods that were promised during the halcyon days of educational technology".

However, it is not the senior administrators, both academic and nonacademic, who are working at the "coal face" of the teaching programs. Those teaching staff who support educational technology are the "clients" 
initiating the production or acquisition of innovative teaching resources. Unfortunately these same people usually do not have input into their institution's budget submissions for Federal and State funding, or to the division and allocation of funds once the institution has received its budget.

In late October, 1986, The Commonwealth Tertiary Education Commission (CTEC) released the Review of Efficiency and Effectiveness in Higher Education in Australia. This Review, together with the Quality of Education in Australia (April 1985) and The Review of TAFE Funding (May 1986) reflect and respond to the Commonwealth Government's concern to absorb the maximum number of people into tertiary education with a minimum increase in public spending. In Junor's (1986) response to CTEC's Review a number of facts emerge to illustrate the Commonwealth Government's "withdrawal" from education funding:

- Between 1976 and 1985, student load (EFTS) increased by 25\%, with a further 3.7\% increase between 1985 and 1986.

- Total government outlays on higher education have not increased in real terms since 1975, remaining steady at 52.1 billion per annum.

- Capital expenditure in 1985 was less than 20\% of the real level in 1975.

- Operating grants per full time student have declined by $8 \%$ in the past decade and the student/staff ratios have declined by $11 \%$.

The NSW Higher Education Board's submission for 1988-90 Triennium (p.103) records that between 1978 and 1985 in NSW, there has been a 44\% real decline in library funding per EFTS, a 29\% decline in maintenance funding and a $47 \%$ decline in equipment funding.

It is against this familiar (and alarming) economic background that we view the current state of Audiovisual Departments in Australian CAE's. The research aimed to obtain current data relating to the following areas:

- an institution profile

- the state of audiovisual equipment

- audiovisual staff profile

- production of audiovisual resources

- Audiovisual Department profile 
A $72 \%$ response rate to the mailed questionnaire was considered to be sufficient to give a valid and reliable picture of the Audiovisual Departments in Australian CAE's. A brief summary of the responses follows.

\section{Institution profile}

The management structure of the responding institutions varies. However, the size of the institution does not seem to determine the 'style' of the management structure or the autonomy of the Audiovisual Department, although autonomy was less frequent in larger institutions. Only 15\% of the Heads of Audiovisual Departments are responsible directly to the Principal, Deputy Principal or the Registrar, while 85\% of the Heads are responsible to the Head of a Centre or Unit within which the Audiovisual Department operates. Of the $85 \%$ of Audiovisual Departments within another Centre or Unit, $27 \%$ are within the Library or Information Resources Centre. Comments received indicate that where Audiovisual Departments operate within another Centre or Unit, many managers believe the funding priorities of the Centre or Unit resulted in reduced funding being available for the Audiovisual Department; and to petition funding supplements from above the Head of the Centre or Unit was not politic.

Fifty eight percent of the institutions were multi-campus institutions. The logistics of multi-campus institutions pose problems for all divisions of management and services, including the Audiovisual Department. Seventy percent of Departments were expected to offer audiovisual equipment training on each campus and $61 \%$ of the Departments undertook audiovisual resource production on each campus of the institution. Forty eight percent of respondents conducted both training and production services on each of the campuses of the institution. It should be noted that multi-campus institutions ranged from two to six campuses.

The 1970s saw the establishment of the majority of Audiovisual Departments throughout the Colleges of Advanced Education sector in Australia. Sixty four percent of the Departments were established between 1976 and 1979. Sixty seven percent of the Institutions were established within the capital city environs of their state.

\section{Hardware}

With regard to depreciation and replacement of equipment, $79 \%$ of respondents commented that audiovisual equipment was evaluated for 
replacement on the basis of increasing maintenance costs, difficulty in obtaining spare parts, and equipment becoming obsolete. However, only eighteen percent of the respondents noted that their Department followed a formal audiovisual Equipment Replacement or Depreciation Policy. The responses show that within eight to twenty months, all categories of equipment included in the questionnaire will have reached the assessed life expectancy. The majority Of comments stated that budgets rarely allowed the 'luxury' of replacing equipment, with the results being increased maintenance time and costs, students using obsolete equipment and quality lost in the production of resources.

\section{Staff}

Between 1980 and 1985, 45\% of Audiovisual Departments gained staff members, compared to $30 \%$ of Departments which lost staff members. For the same period, $21 \%$ of Departments retained a static staff profile. Staff gained or lost between 1980 and 1985 covered the whole range of expertise usually found in Audiovisual Departments. The consequences of this action mean that professional production skills, para-professional skills involving equipment demonstration and classroom services, and clerical/secretarial support were lost by many Departments. Twenty-four percent of the Departments' staffing profile included academic staff who conductod lectures in equipment operation, audiovisual production, or were involved in writing, teaching, and evaluating courses in educational technology. Of those respondents who did request additional staff for 1986, none were approved by institution management. Consequently, in 1986 static staff profiles remained and previously 'lost' positions were not filled. The most frequent positions requested by the Heads of Audiovisual Departments in 1986 were Technical Assistants (23\%), Graphic Artists $(13 \%)$, Clerical Assistants (13\%), and Audiovisual Officers (10\%).

Attending courses and conferences ranks highly as a strategy for staff development within Audiovisual Departments. Seventy six percent of respondents noted that they and/or their staff would attend one or more courses or conferences during 1986. However, $15 \%$ of respondents indicated that only senior audiovisual staff would attend any courses or conferences during 1986. Thirty six percent of the institutions provide internal staff development courses which the respondents consider are appropriate for audiovisual staff. It would appear that the larger the institution, the greater the range of internal staff development courses offered to the institution's staff with more internal development courses appropriate to audiovisual staff. 


\section{Resource production}

On the question of identifying the Department's clients in the area of resource production, responses indicate that $85 \%$ of Audiovisual Departments produce resources for their institution. Seventy nine percent of Departments produce resources specifically for academic staff. Fifty five percent produce resources for external agencies, which would indicate that these Departments are forced to raise funding from outside the institution. Resource production figures show that the Departments within larger institutions are producing more video, slide/sound, photographic and audio resources than are the smaller institutions' Audiovisual Departments.

These production figures indicate that demand for resource production increases with the growth of the institution, but the Audiovisual Department must also expand in order to meet these demands from academic and administrative staff and the students. Although $64 \%$ of respondents indicated that there has been an increased demand for audiovisual production since 1980 , only $45 \%$ of the Departments had increased their staff profile since 1980 with no staff increases recorded in 1986. This comparison would suggest that either the audiovisual staff are working under a continual overload of production demands, or the philosophy of service has changed, possibly from instruction or classroom service to production. Sixty percent of respondents cited requests from academic staff as the main reason for increased production since 1980. Thirty nine percent of the respondents commented that they had actively promoted the Department's production service and this promotion had successfully resulted in more requests for resource production.

Academic staff demands for Australian content in their teaching resources resulted in a 30\% increase in production requests between 1980 and 1986 . As well as an increased demand for production services, 55\% of the institutions recently began offering Nurse Education Courses resulting in more demands on the classroom services and training courses of most audiovisual Departments. However, only $18 \%$ of the respondents Departments received additional funding for hardware to assist in the provision of these services to Nursing staff and students.

\section{Funding}

In comparing all the budget category figures revealed by the respondents, over $90 \%$ of the budget submissions had increased since 1980 . While $25 \%$ of respondents received less funding for 1986 than they had requested in their budget submissions, $18 \%$ received funding equal to their submissions, and 3\% received more than they had requested in their budget submissions. As $54 \%$ of respondents declined to reveal their 
Department's budget submissions or allocations these figures can only indicate a possible, though probable, trend amongst Audiovisual Departments.

While demands for the services of Audiovisual Departments are increasing with very few Departments benefiting from an increase in funding or staff, many respondents believed computer equipment and computer staff were responsible for this dilemma. Computing equipment and computer education have become a basic part of most disciplines in the tertiary sector. The ACDP Report on Equipment Funding in Colleges of Advanced Education found that funding for computing equipment increased from $22.5 \%$ in 1981 to $52.98 \%$ in 1985 of the total equipment funds available within the institutions. Institution managers have determined that computers are a priority and the funding increases between 1981 and 1985 are indicative of a possible belief that the services provided by Audiovisual Departments are a luxury which can be cut in times of financial constraint.

If the effect of inflation on any funding given to Audiovisual Departments since 1980 is examined, it can be seen that cuts in funding have only been exacerbated by the drop in real purchasing power. By using $10 \%$ as the average yearly inflation figure, funding required just to remain at the same level in 1980 must be increased by $95 \%$ in 1988. Should the Audiovisual Department's funding not be in conflict with the funding of computer equipment for the institution, the Department must receive funding at a level that will, at a minimum, overcome the effects of inflation.

\section{Training Courses}

It was noted earlier that $70 \%$ of Audiovisual Departments conducted training courses. Sixty seven percent of those Departments train students in the operation of audiovisual equipment and 52\% in the production of audiovisual materials. Training was carried out in other fields, to a lesser extent, such as television production $(27 \%)$, radio production $(12 \%)$, film production $(6 \%)$, and photography $(24 \%)$. While the majority of Audiovisual Departments are involved in training students in the operation of audiovisual equipment, and equipment specific to other production areas, $72 \%$ of the respondents noted that the quantity of equipment available for these training sessions was inadequate for their needs. Generally, practical sessions were being repeated many times, class sizes were increasing and students were receiving less practical experience than is necessary to reach a competent level. Compounding the problem of the inadequate quantity of equipment for training is the age of the equipment used for training sessions. Respondents noted that the age of 
the equipment resulted in practical sessions being regularly disrupted through equipment failure, and students were not being trained in the use of current technology.

\section{Conclusion}

The current profile of Audiovisual Departments in Australian CAEs is not an encouraging scenario-funding cuts, rising costs, static or reduced staff profiles, aging equipment either past its replacement date or rapidly approaching obsolescence, increased demands for the provision of training courses albeit with old equipment in insufficient quantities, providing services on multi-campus institutions (some of which were formed through the amalgamation of institutions as part of a government cost-saving initiative), and providing additional services to new nursing students and staff for those Departments whose institutions established Schools of Nursing in 1984.

When administrators are faced with reduced funding, cuts are usually imposed on expenditure to the Audiovisual Department, library, and equipment maintenance. While absorbed in the management of human and financial resources and the cost effectiveness of the institution's operations, administrators look for short term measures to "balance the books". The productivity of the institution is reflected by the number of graduating students at each year's end - how effectively and efficiently those graduates were "produced" is often, it would seem, of little importance.

Managers of Audiovisual Departments in most Colleges of Advanced Education are generally not included in the institution's budget decisions, or planning for future goals and directions. This exclusion from institution planning means that educational technologists cannot contribute to the design and implementation of improved academic instruction through the integration of traditional teaching methods and educational technology.

Because of the effects of funding cut-backs, combined with tile effects of the depreciation of the Australian dollar, equipment funding is at a crisis level in the higher education sector. Should the Commonwealth Government continue with minimal funding levels delaying further the replacement of equipment, the costlier it will become to operate maintenance programs for equipment with built-in obsolescence. Audiovisual production, computers and scientific equipment are areas where technological change accelerates, along with the need for equipment replacement. The case must be strongly argued that investment in equipment replacement and "catch up" funds must be allocated in order to avert a later and costlier crisis. 
The start of a continuing Government trend towards reducing funding levels for tertiary education began about 1980. As the majority of Audiovisual Departments were established in the 1970s, 1980 was chosen not only because it was the turning point regarding tertiary funding cuts, but 1980 saw the beginning of another decade where the progress of Audiovisual Departments could be measured. Not only has funding been decreasing for Audiovisual Departments, but the real costs have increased as the majority of equipment items are imported and the value of the Australian dollar has dropped significantly since 1983. For example, in 1984 there were approximately 233 yen to the Australian dollar. In 1988, the rate hovers around 100 yen to the dollar. Not only are Audiovisual Departments receiving less funding, but the funding is buying less in real terms.

As a result of this survey into the current state of Audiovisual Departments in Australian Colleges of Advanced Education, the following recommendations are made:

- The Australian Committee of Directors and Principals of Colleges of Advanced Education should urgently petition the Federal Government to grant "catch up" funding to allow Audiovisual Departments to replace obsolete equipment that has built up over the last eight to twelve years, and purchase new hardware and software, so that training courses, classroom services and resource production reaches a level suitable for the provision of an acceptable standard of service.

- The effects of devaluation and inflation on the purchasing power of the Australian dollar should be immediately recognised and rectified through the funding of equipment grants to Colleges of Advanced Education.

- To maintain levels of service and maintain equipment at an optimum level, in addition to an injection of "catch up" funding, Audiovisual Departments should be allocated annual funding specifically for replacement of equipment as items reach their full life expectancy. This replacement funding should be in addition to yearly operating costs, not skimmed off the audiovisual budget, thus reducing available funds even further.

- The demands placed upon Audiovisual Departments must be carefully examined by institution management to determine the staffing profile required to successfully carry out the provision of audiovisual services. 
- Managers of Audiovisual Departments must identify the training courses and conferences suitable to develop the skills and competencies of their staff in order to promote a quality service to the institution's staff and students. Staff development funding should not be considered by the Institution as a luxury item.

It is also recommended that further research be undertaken in the following areas:

- The employment rate of graduating students in their chosen industry / profession be investigated to determine whether the current use of obsolete technologies in their courses and practical sessions has resulted in a lack of industry credibility in their qualifications.

- The budget allocations made to support areas such as Audiovisual Departments, Libraries and Computing Centres, and the mechanisms used to determine the funding levels for these support areas be investigated to determine policies.

- Investigate the expectations which academic and senior administrative staff of the institution have of Audiovisual Departments, levels of service and the philosophy of educational technology as an effective means to increase understanding and communication in the teaching process.

- The content of staff training programs which will assist audiovisual staff contribute to the provision of improved services by their Department be determined and appropriate courses developed.

If these recommendations were to be put into effect, the deficiencies and problems, as revealed by this research could be remedied. We may never be able to return to the "halcyon days of educational technology" but we must continue to invest our energies in the promotion of educational technology strategies to improve the efficiently and effectiveness of communication and learning.

\section{Reference Note}

1. The term 'Audio Visual Department' (hereafter Audiovisual Department) is used throughout this article to represent the range of departments who participated in the research e.g. Educational Technology Centres, Media Resources Units, Resource Production Units, Teaching Resources Centres, Instructional Media Centres, etc. 


\section{Bibliography}

Commonwealth Tertiary Education Commission (1986). Review of Efficiency and Effectiveness in Higher Education, Canberra: Australian Government Publishing Service.

Commonwealth Tertiary Education Commission (1986). The Review of TAFE Funding, Canberra: Australian Government Publishing Service.

Hedberg, J. G. (1980). New roles for educational technology. Australian Society of Educational Technology Yearbook, pp.21-27.

Junor, A. (1986). Response to the Review of Efficiency and Effectiveness in Higher Education, NSW Teachers Federation, Sydney, Australia.

Myers, N. T. (1979). "Gold or Dust"? Instructional Technology in Higher Education. Australian Society of Educational Technology Yearbook, pp.4554.

NSW Higher Education Board (1986). Submission for 1988-90 Triennium. Sydney: NSW Higher Education Board.

Quality of Education Review Committee (1985). The Quality of Education in Australia. Report of the Review Committee. Canberra: Australian Government Publishing Service.

Steele, J. (1987). EdTech and the Review of Efficiency and Effectiveness in Higher Education, Australian Journal of Educational Technology, 2(2), 129138. http:/ / www.ascilite.org.au/ ajet/ajet2 / steele.html

Author: Mark Norman has worked in the field of educational technology, and audiovisual services in the tertiary sector for over fifteen years as a teacher, producer and manager. Macarthur Institute serves the population of the south-west of Sydney with campuses at Milperra and Campbelltown. Audiovisual Services provided at the Institute include classroom services, training programs, maintenance and installation of equipment and systems, and the production of teaching and promotional resources across both campuses.

Please cite as: Norman, M. (1988). In flight or in plight? The current state of audio visual departments in Australian CAEs. Australian Journal of Educational Technology, 4(2), 59-69.

http:/ / www.ascilite.org.au/ajet/ajet4/norman.html 